\title{
POTENTIAL USE OF WATERGUARD AS A DISINFECTANT FOR DOMESTIC WATER USE
}

\author{
Yohana $L^{1}$. and Mashauri, D. $A^{2}$. \\ ${ }^{1}$ PhD candidate, Water Resources Engineering Department, University of Dar es Salaam ylawi@yahoo.com. \\ ${ }^{2}$ Professor, Water Resources Engineering Department, University of Dar es Salaam, mashauri@udsm.ac.tz
}

\begin{abstract}
Water Guard which consists of $0.75 \%$ sodium hypochlorite (chlorine-based water disinfectant solution) has been identified as an alternative method for treatment of domestic drinking water. The aim of this study was to investigate the effectiveness of Water Guard in disinfecting drinking water from different sources drawn from Kinondoni district, Dar es Salaam as well as to establish appropriate dosage that can be used during the treatment. Results showed that, a dose of $4.0 \mathrm{~mL}$ per 20 litrer of water guard is sufficient for disinfection of urban water sources. The above prescribed doses provide $100 \%$ disinfection efficiency with residue chlorine of less than $0.3 \mathrm{mg} / \mathrm{l}$. Water with turbidity values of 30-35 NTU, chlorine dosage of $8 \mathrm{~mL} / 20$ litres is recommended and this gives residue chlorine of $0.3-0.5 \mathrm{mg} / \mathrm{L}$. From this study, it can be concluded that, Water guard is effective against pathogen and that there is an increase of residue chlorine as the dosage increases irrespective of from which source the water was drawn. Also the safety of water is obtained even where the residual chlorine is less that $0.1 \mathrm{mg} / \mathrm{l}$. However, there are health implications associated with the use of Water Guard which need further research
\end{abstract}

Key words

Water Guard, pathogens, effectiveness, dosages, disinfection, residue chlorine.

\subsection{INTRODUCTION}

Poor sanitation in developing countries has been one of the causes of water borne diseases such as cholera, typhoid, dysentery and diarrhea. Foe instances, Diarrhea disease which are frequently transmitted by contaminated water, continue to be a leading cause of morbidity and mortality among children under 5 years of age in developing countries. Estimates of annual total mortality from diarrhea disease range from 2.5-3.5 million (Macy and Quick, 2002). World Health Organization (WHO) estimates that more than 25,000 people throughout the world die every day from waterborne diseases. Every year, nearly 1.5 billion people mostly children under the age of five suffer from preventable waterborne diseases such as cholera, typhoid fever, amoebic dysentery, bacterial gastroenteritis and viral diseases such as hepatitis.

Although there is a supply of treated water especially in urban areas, but this supply is very low e.g. in Dar es Salaam with a population of about 2.5million (2002 Census) the supply is only about $70 \%$. This implies that, some population depends on the other sources of water such as wells, rain and stream waters which are of suspicious quality. There is also a doubt about the quality of treated water in such a way that one can not use directly tap water without boiling. Water must be of high quality and should present no risks to the users by its physical, chemical and biological quality. These and other factors call for an alternative solution which can be affordable by many, easily utilized and effectively means of water treatment. The application of disinfecting chemicals is essential in order to prevent water borne diseases whose transmission route is by oral ingestion. Sodium hypochlorite with a trade name Water Guard has been identified as an effective water treatment for domestic water use (Mmbando. 2004 and Mwambete and Manyanga, 2006). Water Guard is the disinfecting chemical which kills micro organism when applied in contaminated water. It also oxidizes organic matter if the treated water is turbid and contains organic content. The purpose of disinfecting raw water is to destroy pathogenic organisms and thereby eliminate and prevent waterborne diseases like typhoid. Diarrhea, Cholera, amoebic dysentery etc. 
This study aim to investigate the effectiveness of Water Guard as disinfectant against pathogens in the treatment of drinking water from different sources.

\subsection{Chemistry of Water Guard (Sodium hypochlorite)}

Water guard is one of the many disinfectants applied in the course of water treatment process whose chemical name is sodium hypochlorite and other common names include liquid bleach or soda beach, with a 74.5 relative molecular mass and an empirical formula $\mathrm{NaClO}$. Sodium hypochlorite may be prepared by absorbing chlorine gas in cold sodium hydroxide solution:

$2 \mathrm{NaOH}+\mathrm{Cl}_{2} \rightarrow \mathrm{NaCl}+\mathrm{NaClO}+$

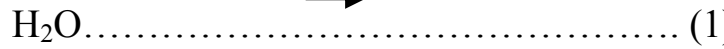

Water Guard has an average chloride content of $4799 \mathrm{mg} / \mathrm{l}$ at an average $\mathrm{pH}$ value of 11.4 . However, the chlorine content in Water Guard deteriorates considerably in value as its life span also equally decreases (Mmbando, 2004). The term free available chlorine is used to refer to the sum of the concentration of molecular chlorine $\left(\mathrm{Cl}_{2}\right)$, hypochlorous acid (HOCL), and hypochlorite ion $\left(\mathrm{OCL}^{-}\right)$, each expressed as available chlorine. Free available chlorine is many times is more powerful than the combined available chlorine as a bactericide (Butterfield 1943 and Whitlock 1953). The average free available chlorine content of water guard as at $30^{\circ} \mathrm{C}$ is $0.13 \mathrm{mg} / \mathrm{l}$ at an average $\mathrm{pH}$ value of 11.2. Research has shown that, chlorine content is very high in Water Guard just after being manufactured and decrease gradually as the expiring date approaches.

\subsubsection{Mechanism of action}

Like all hypochlorites, sodium hypochlorite is a salt of hypochlorous acid. In water, it completely dissociates into the sodium cation $\mathrm{Na}^{+}$and the hypochlorite anion $\mathrm{CIO}^{-}$while a small portion hydrolyses into sodium hydroxide and hypochlorous acid (Pecór et al., 1999)

$$
\begin{aligned}
\mathrm{NaOCl}= & \mathrm{H}_{2} \mathrm{O} \ll \mathrm{NaOH}+\mathrm{HOCl} \ll \mathrm{Na}^{+}+\mathrm{OH}^{-}+ \\
& \left.\mathrm{H}^{+}+\mathrm{OCl}^{-} \ldots \ldots \ldots \ldots \ldots . . . . .2\right)
\end{aligned}
$$

The chemical reactions verified between organic tissue and sodium hypochlorite are shown in schemes 1-3

Scheme 1. Saponification reaction.

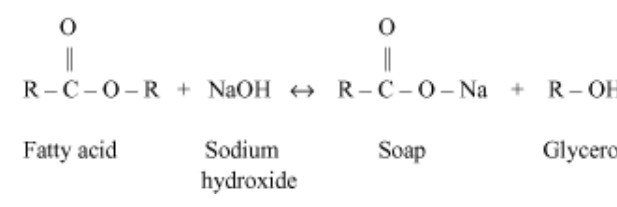

Scheme 2. Amino acid neutralization reaction.

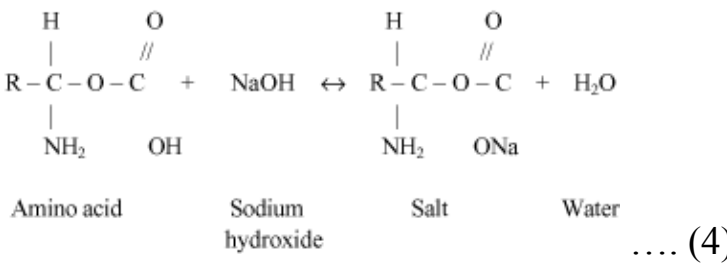

Scheme 3. Chloramination reaction.

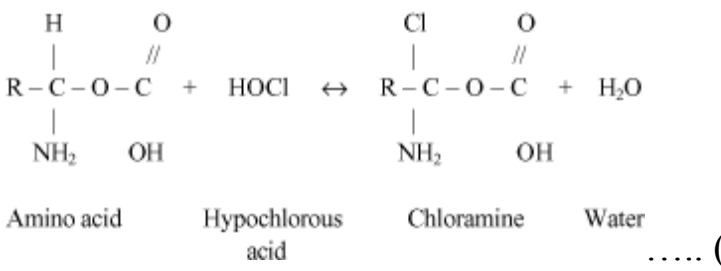

Interpreting these chemical reactions, it can be observed that sodium hypochlorite acts as an organic and fat solvent degrading fatty acids, transforming them into fatty acid salts (soap) and glycerol (alcohol). That reduces the surface tension of the remaining solution. Schemes 1saponification reaction, equation 3 .

Sodium hypochlorite neutralizes amino acids forming water and salt (scheme 2neutralization reaction, equation 4) with the exit of hydroxyl ions, there is a reduction of $\mathrm{pH}$. Hypochlorous acid, a substance present in sodium hypochlorite solution, when in contact with organic tissue acts as solvent, releases chlorine that combined with the protein amino group, forms chloramines (scheme 3chloramination reaction, equation 5). Hypochlorous acid $\left(\mathrm{HOCl}^{-}\right)$and hypochlorite ions $\left(\mathrm{OCl}^{-}\right)$lead to amino acid degradation and hydrolysis. The chloramination reaction between chlorine and the amino group $(\mathrm{NH})$ forms chloramines that interfere in cell metabolism. Chlorine (strong oxidant) presents 
antimicrobial action inhibiting bacterial enzymes leading to an irreversible oxidation of $\mathrm{SH}$ groups (sulphydryl group) of essential bacterial enzymes.

\subsection{How to use Water Guard}

Sodium hypochlorite has been used for the disinfection of drinking water, at a concentration equivalent to about 1 litre of household beach per 4000 litres of water. In Tanzania, the manufacturer of Water Guard recommends a dose of $0.375 \mathrm{ml} / 1$, which is equivalent to $5 \mathrm{ml} / 1$ (a cap-full of Water Guard bottle) in 20 litres of water. But various studies suggest that, the exact amount required depends on the water chemistry temperature, contact time, and presence or absence of sediment e.g. water with turbidity values of 30-35 NTU chlorine dosage of $8.0-\mathrm{ml} / 20$ litres container is recommended and this gives residue chlorine of $0.3-0.5 \mathrm{mg} / 1$. People should therefore be aware when disinfecting turbid water; the water has to settle overnight followed by filtration using a clean white piece of cloth. The use of chlorinebased disinfectants in domestic water although widespread, has led to some controversy due to the formation of small quantities of harmful by products such as chloroform.

\subsection{Methodology and study site description}

\subsection{Description of study site}

Sample of analysis were collected from various sources in Kinondoni district, Dar es Salaam city. They city is located at $6^{0} 48$, South and $39^{\circ} 17$, East with mean monthly temperatures ranging from $15^{\circ} \mathrm{C}$ to $36^{\circ} \mathrm{C}$ and mean monthly rainfall ranging from $25 \mathrm{~mm}$ to $290 \mathrm{~mm}$ and average annual precipitation of $1066 \mathrm{~mm}$. It should also be noted that, like in most developing countries cities, Dar es Salaam is characterized with high population density, unplanned settlement, poor supply of water services and inadequate sewerage facilities. All these factors have led to poor sanitation environment which bring health concern to the public

\subsection{Methodology}

The water collected for laboratory analysis with regard to the effectiveness of Water Guard as a disinfectant include well water, water vendors, tap water and storage water. Standard sampling procedures were followed and the aim was to obtain samples that are representative of the water to be examined. All analyses were carried out in water resources engineering laboratory, University of Dar es Salaam in accordance with the standard Methods (APHA 1992) and included, temperature, $\mathrm{pH}$, turbidity, residual chlorine, and faecal coliform. Dosages of 0.2 , $0.3,0.35,0.4,0.8$ and $1.6 \mathrm{~m} \mathrm{~L} / \mathrm{L}$ were applied to water from different sources and followed by allowing reaction time of 30 minutes after which pathogens (total coliforms and faecal coliforms) and residual chlorine concentration were determined in each sample. These dosages were established by initially applying them to contaminated water and shallow well water so as to determine their effectiveness against pathogens.

\subsection{RESULTS AND DISCUSSION}

\subsection{Dosages and efficacy of Sodium Hypochlorite}

A total of 8 water samples from two water sources with turbidity values of 5 and 30 NTU were dosed with disinfectant of $0.2,0.3,0.35$ and $0.4 \mathrm{~mL} / \mathrm{L}$. Raw water parameters are presented on table 3.1. In clear water (5NTU) the dosage of $0.4 \mathrm{ml} / 1$ gave residue chlorine of above the limit of $0.5 \mathrm{mg} / \mathrm{L}$ while turbid water resulted into acceptable value as clearly shown on table 3.2. 
Table 3.1. Parameters of raw water contaminated with coliform bacteria before disinfections

\begin{tabular}{|l|l|l|l|}
\hline Type of water & Turbidity (NTU) & Total coliform (TC)/100mL & Faecal coliform (FC)/100mL \\
\hline Contaminated water & 5 & 400 & 31 \\
\hline Shallow well water & 30 & 400 & 35 \\
\hline
\end{tabular}

Table 3. 2. Water quality parameters after disinfection at different dosage

\begin{tabular}{|c|c|c|c|c|c|c|}
\hline \multirow{2}{*}{$\begin{array}{l}\text { Dosage } \\
\mathrm{ml} / \mathrm{L}\end{array}$} & \multicolumn{3}{|c|}{ Contaminated water with turbidity 5 NTU } & \multicolumn{3}{|c|}{ Shallow well water with turbidity $30 \mathrm{NTU}$} \\
\hline & $\mathrm{TC} / 100 \mathrm{~mL}$ & $\mathrm{FC} / 100 \mathrm{~mL}$ & $\begin{array}{ll}\text { Residue } & \mathrm{Cl}_{2} \\
\mathrm{mg} / \mathrm{L} & \end{array}$ & $\mathrm{TC} / 100 \mathrm{~mL}$ & $\mathrm{FC} / 100 \mathrm{~mL}$ & $\begin{array}{l}\text { Residue } \\
\mathrm{Cl} 2 \mathrm{mg} / \mathrm{L}\end{array}$ \\
\hline 2 & 400 & 31 & $<0.1$ & 300 & 20 & Nil \\
\hline 3 & Nil & Nil & 0.25 & 200 & 10 & Nil \\
\hline 3.5 & Nil & Nil & 0.4 & 15 & 2 & $<0.1$ \\
\hline 4 & Nil & Nil & 0.6 & Nil & Nil & 0.2 \\
\hline
\end{tabular}

From Table 3.1 and 3.2 it can clearly be observed that the effectiveness of Water Guard as disinfectant is greatly influenced by its concentration and water turbidity in question. For instance, the dosage of $0.4 \mathrm{ml} / \mathrm{L}$ was $100 \%$ efficiency in killing bacteria while the concentration of $0.35 \mathrm{ml} / \mathrm{L}$ did not kill completely all the bacteria. Also high turbidity significantly affect the efficient to water guard in disinfection as $3 \mathrm{ml} / \mathrm{L}$ of water guard was $100 \%$ efficient in water with turbidity $5 \mathrm{NTU}$ and the same concentration was ineffective against water with turbidity of $30 \mathrm{NTU}$. On the other hand, it is necessary to control the concentration of residue chlorine to $0.2-0.3 \mathrm{mg} / \mathrm{l}$ as recommended by $\mathrm{WHO}$, and the allowable limit is $0.5 \mathrm{mg} / \mathrm{L}$. From the result above, residue chlorine increases with dosage and decreases with increasing water turbidity. Thus it is necessary to have a balance between the concentrations of water guard which can completely kill all the pathogens with permissible residue chlorine, bearing in mind that the effectiveness of water guard is also influenced by turbidity, $\mathrm{pH}$, Temperature water chemistry in question and contact time (Mmbando, 2004).

Based on the results obtained in table 3.1 and 3.2 , dosage of $4 \mathrm{~mL}$ and $8 \mathrm{~mL}$ of Water Guard were selected to be used throughout the experiment, $4 \mathrm{ml} / \mathrm{L}$ was considered as the lowest effective dose while $8 \mathrm{ml} / \mathrm{L}$ was considered to be the highest. It is necessary to consider both, the lowest and highest effective concentration so as to set the dosage which should be effective against pathogens and at the same time has the minimum allowable residue chlorine i.e. $0.3 \mathrm{mg} / \mathrm{L}$.

The dosage of $4 \mathrm{~mL}$ was applied in 20 litres containers as it is shown in Table 3.3, 3.4 and 3.5. Then after each five minute contact time $1 \mathrm{ml}$ of disinfected water sample was taken for plating, which enables the faecal total coliform remaining in water samples to be counted after an incubation period of 24 hours at $44.5^{\circ} \mathrm{C}$. Samples were collected from three different locations in Kinondoni districts, Ubungo Msewe, Kinondoni and Kawe.

Table 3.3 Water quality results before and after disinfection (Ubungo Msewe)

\begin{tabular}{|l|l|l|l|l|l|l|l|l|}
\hline & & \multicolumn{3}{|c|}{ Before treatment } & \multicolumn{2}{|l|}{ After treatment } & \\
\hline Source & $\mathrm{pH}$ & $\begin{array}{l}\text { Turbidity } \\
\text { (NTU) }\end{array}$ & TC/100ml & FC/100ml & $\begin{array}{l}\text { Dosage } \\
\text { Ml/20L }\end{array}$ & TC/100ml & FC/100ml & $\begin{array}{l}\text { ResidueCl }_{2} \\
(\mathrm{mg} / \mathrm{L})\end{array}$ \\
\hline Borehole & 8.0 & 2.7 & 1 & Nil & 4 & Nil & Nil & 0.2 \\
\hline $\begin{array}{l}\text { Shallow } \\
\text { well }\end{array}$ & 7.9 & 27.5 & 20 & Nil & 4 & Nil & Nil & $<0.1$ \\
\hline $\begin{array}{l}\text { Water } \\
\text { vendors }\end{array}$ & 7.6 & 5.8 & Nil & Nil & 4 & Nil & Nil & 0.2 \\
\hline $\begin{array}{l}\text { Tap } \\
\text { water }\end{array}$ & 7.8 & 2.5 & Nil & Nil & 4 & Nil & Nil & 0.2 \\
\hline
\end{tabular}

64 
Table 3.4 Water quality results before and after disinfection (Kinondoni)

\begin{tabular}{|l|l|l|l|l|l|l|l|l|}
\hline & & \multicolumn{5}{|c|}{ Before treatment } & \multicolumn{3}{|l|}{ After treatment } & \\
\hline Source & $\mathrm{pH}$ & $\begin{array}{l}\text { Turbidity } \\
\text { (NTU) }\end{array}$ & TC/100ml & FC/100ml & $\begin{array}{l}\text { Dosage } \\
\text { Ml/20L }\end{array}$ & TC/100ml & FC/100ml & $\begin{array}{l}\text { ResidueCl } \\
\text { (mg/L) }\end{array}$ \\
\hline $\begin{array}{l}\text { Boreh } \\
\text { ole }\end{array}$ & 8.2 & 2.5 & 110 & 9 & 4 & Nil & Nil & 0.25 \\
\hline $\begin{array}{l}\text { Shallo } \\
\text { w well }\end{array}$ & 7.8 & 30.5 & 150 & 3 & 4 & Nil & Nil & $<0.1$ \\
\hline $\begin{array}{l}\text { Water } \\
\text { vendor } \\
\text { s }\end{array}$ & 7.5 & 7.5 & Nil & Nil & 4 & Nil & Nil & $<0.1$ \\
\hline $\begin{array}{l}\text { Tap } \\
\text { water }\end{array}$ & 7.8 & 3.0 & Nil & Nil & 4 & Nil & Nil & 0.1 \\
\hline
\end{tabular}

Table 3.5 Water quality results before and after disinfection (Kawe)

\begin{tabular}{|l|l|l|l|l|l|l|l|l|}
\hline & & & \multicolumn{2}{|l|}{ Before treatment } & & After treatment & \\
\hline Source & $\mathrm{pH}$ & $\begin{array}{l}\text { Turbidity } \\
\text { (NTU) }\end{array}$ & $\mathrm{TC} / 100 \mathrm{ml}$ & $\mathrm{FC} / 100 \mathrm{ml}$ & $\begin{array}{l}\text { Dosage } \\
\text { Ml/20L }\end{array}$ & TC/100ml & FC/100ml & $\begin{array}{l}\mathrm{ResidueCl}_{2} \\
(\mathrm{mg} / \mathrm{L})\end{array}$ \\
\hline Borehole & 8.0 & 4.5 & 130 & 19 & 4 & Nil & Nil & 0.25 \\
\hline $\begin{array}{l}\text { Shallow } \\
\text { well }\end{array}$ & 8.8 & 32.5 & 450 & 50 & 4 & Nil & Nil & $<0.1$ \\
\hline $\begin{array}{l}\text { Water } \\
\text { vendors }\end{array}$ & 7.5 & 8.5 & 20 & Nil & 4 & Nil & Nil & 0.14 \\
\hline $\begin{array}{l}\text { Tap } \\
\text { water }\end{array}$ & 7.6 & 2.5 & Nil & Nil & 4 & Nil & Nil & 0.1 \\
\hline
\end{tabular}

By considering these results obtained in the second run, $8 \mathrm{~mL}$ of Water Guard was applied only on water with more than 20 NTU turbidity to determine its effectiveness and residue chlorine as it is shown in Table $3.6-8.8 \mathrm{~mL}$ was selected in order to set the highest dosage that can be used for turbid water only as if applied to less turbid water would lead to high concentration of residue chlorine. $4 \mathrm{~mL}$ used in the experiment above was maintained to water with low turbidity to further confirm those results as any amount above that would lead to residue chlorine above $0.5 \mathrm{mg} / \mathrm{L}$ which is not allowed (Refer table 3.2).

Table 3.6 Water quality results before and after disinfection (Ubungo Msewe)

\begin{tabular}{|l|l|l|l|l|l|l|l|l|}
\hline & & \multicolumn{3}{|l|}{ Before treatment } & \multicolumn{3}{l|}{ After treatment } & \\
\hline Source & $\mathrm{pH}$ & $\begin{array}{l}\text { Turbidity } \\
\text { (NTU) }\end{array}$ & TC/100ml & FC/100ml & $\begin{array}{l}\text { Dosage } \\
\text { Ml/20L }\end{array}$ & TC/100ml & FC/100ml & $\begin{array}{l}\text { ResidueCl } \\
\text { (mg/L) }\end{array}$ \\
\hline Borehole & 8.1 & 3.5 & 1 & Nil & 4 & Nil & Nil & 0.25 \\
\hline $\begin{array}{l}\text { Shallow } \\
\text { well }\end{array}$ & 7.8 & 30.5 & 45 & 5 & 8 & Nil & Nil & 0.37 \\
\hline $\begin{array}{l}\text { Water } \\
\text { vendors }\end{array}$ & 7.9 & 8.1 & Nil & Nil & 4 & Nil & Nil & 0.14 \\
\hline $\begin{array}{l}\text { Tap } \\
\text { water }\end{array}$ & 7.4 & 2.7 & Nil & Nil & 4 & Nil & Nil & 0.29 \\
\hline
\end{tabular}


Table 3.7 Water quality results before and after disinfection (Kinondoni)

\begin{tabular}{|c|c|c|c|c|c|c|c|c|}
\hline & & & Before tre & ment & & After treat & ment & \\
\hline Source & $\mathrm{pH}$ & $\begin{array}{l}\text { Turbidity } \\
\text { (NTU) }\end{array}$ & $\mathrm{TC} / 100 \mathrm{ml}$ & $\mathrm{FC} / 100 \mathrm{ml}$ & $\begin{array}{l}\text { Dosage } \\
\text { Ml/20L }\end{array}$ & $\mathrm{TC} / 100 \mathrm{ml}$ & $\mathrm{FC} / 100 \mathrm{ml}$ & $\begin{array}{l}\text { ResidueCl } \\
(\mathrm{mg} / \mathrm{L})\end{array}$ \\
\hline Borehole & 8.0 & 3.5 & 13 & 3 & 4 & Nil & Nil & 0.21 \\
\hline $\begin{array}{l}\text { Shallow } \\
\text { well }\end{array}$ & 7.6 & 32.5 & 40 & 10 & 8 & Nil & Nil & 0.35 \\
\hline $\begin{array}{l}\text { Water } \\
\text { vendors }\end{array}$ & 7.4 & 8.5 & 2 & Nil & 4 & Nil & Nil & 0.1 \\
\hline $\begin{array}{l}\text { Tap } \\
\text { water }\end{array}$ & 7.8 & 2.7 & Nil & Nil & 4 & Nil & Nil & 0.24 \\
\hline
\end{tabular}

Table 3.8 Water quality results before and after disinfection (Kawe)

\begin{tabular}{|c|c|c|c|c|c|c|c|c|}
\hline & & & \multicolumn{2}{|c|}{ Before treatment } & & \multicolumn{2}{|c|}{ After treatment } & \\
\hline Source & $\mathrm{pH}$ & $\begin{array}{l}\text { Turbidity } \\
\text { (NTU) }\end{array}$ & $\mathrm{TC} / 100 \mathrm{ml}$ & $\mathrm{FC} / 100 \mathrm{ml}$ & $\begin{array}{l}\text { Dosage } \\
\text { Ml/20L }\end{array}$ & $\mathrm{TC} / 100 \mathrm{ml}$ & $\mathrm{FC} / 100 \mathrm{ml}$ & $\begin{array}{l}\text { ResidueCl }{ }_{2} \\
(\mathrm{mg} / \mathrm{L})\end{array}$ \\
\hline Borehole & 7.8 & 3.5 & Nil & Nil & 4 & Nil & Nil & 0.25 \\
\hline $\begin{array}{l}\text { Shallow } \\
\text { well }\end{array}$ & 8.6 & 29.5 & 15 & Nil & 8 & Nil & Nil & 0.36 \\
\hline $\begin{array}{l}\text { Water } \\
\text { vendors }\end{array}$ & 7.5 & 7.5 & Nil & Nil & 4 & Nil & Nil & 0.2 \\
\hline $\begin{array}{l}\text { Tap } \\
\text { water }\end{array}$ & 7.6 & 2.5 & Nil & Nil & 4 & Nil & Nil & 0.28 \\
\hline
\end{tabular}

Furthermore, the tests continued using $16 \mathrm{~m} \mathrm{~L}$ of Water Guard where water from river, tap water and open well were treated. The objective of this experiment was to determine the amount of residue chlorine. River water with a turbidity value of 237 NTU and Open well with turbidity value of 276 NTU were left to settle for $24 \mathrm{hrs}$ then filtered followed by disinfection. The results obtained are presented on Table 3.9. As indicated in table 3.9, the dosage of $16 \mathrm{~mL}$ Water Guard turbid water lead to residue chlorine above the allowable limit i.e. 0.5, therefore this dosage can not be adopted.

Table 3.9. Disinfection of water with $16 \mathrm{~mL}$ (Water Guard)

\begin{tabular}{|l|l|l|l|}
\hline Source & $\begin{array}{l}\text { Turbidity } \\
\text { NTU }\end{array}$ & $\begin{array}{l}\text { Dose } \\
\text { M1/20Litres }\end{array}$ & $\begin{array}{l}\text { Residual } \\
\text { Chlorine } \\
\text { mg/L }\end{array}$ \\
\hline River & 47.5 & 16 & $>1.0$ \\
\hline $\begin{array}{l}\text { Tap } \\
\text { water }\end{array}$ & 2.5 & 16 & $>1.0$ \\
\hline $\begin{array}{l}\text { Open } \\
\text { well }\end{array}$ & 35.6 & 16 & $>1.0$ \\
\hline
\end{tabular}

From the present study, a dose of $4 \mathrm{~mL}$ per 20 litre capacity container is sufficient for disinfection of urban water. This is due to the fact that water is already disinfected before entering the distribution system for the case of tap water and vendor's water. The above prescribed doses provide $100 \%$ disinfection efficiency with residue chlorine of less than $0.3 \mathrm{mg} / \mathrm{l}$ (WHO a guideline for residue chlorine is $0.2-0.3 \mathrm{mg} / 1$ and allowable limit is $0.5 \mathrm{mg} / \mathrm{l}$ ). Thus, based on this observation, Water Guard is very effective in water treatment.

Another study by Mmbando (2004) in Dar es Salaam city reveals, all collected well water samples showed no faecal coliforms only after a contact time of 5 minutes. This indicate the higher inactivation rate of Water Guard dose of $0.375 \mathrm{ml} / 1$, which is equivalent to $5 \mathrm{ml} / 1$ (a cupfull of Water Guard) in 20 litres of water given by the manufacturer. However its inactivation rate decreases as life span of a particular batch decreases, which cause increase in contact time. A $16.7 \%$ solution stored at $26.70 \mathrm{C}$ will lose $10 \%$ of its strength in 10 days, $20 \%$ in 25 days and $30 \%$ in 43 days (Metacalf and Eddy, 1995). In the other study by Manyanga and Mwambete (2006) while investigating the microbial quality of drinking water in Dar es salaam and use of Water Guard as disinfectant, showed that, taps, streams and shallow wells water sources were 
all heavily contaminated with pathogens. But appropriate use of Water Guard reduces the level of microbial contamination significantly. In this study the assayed Water Guard was found to be $100 \%$ efficacious in treating the samples to a level within the WHO safety standards as well as Tanzania standards, hence it fit for disinfecting water for human use. Thus, it can be indicated that, water guard is indeed, effective in killing microorganisms present in various water samples

Though Water Guard has 100\% efficacious against pathogens, that efficiency can be affected by temperature, $\mathrm{pH}$ and organic matter concentration among other factors. For instance, temperature of $15^{\circ} \mathrm{C}$ the inactivation rate of $0.39 \mathrm{~g} / 1$ Water Guard is low compared to at $30^{\circ} \mathrm{c}$ and $40^{\circ} \mathrm{C}$. Low temperature causes delay in disinfection such that the difference in kill rate of bacteria between temperature of 2 and $20^{\circ} \mathrm{c}$ is noticeable both with free and combined chlorine (Mmbando, 2004). A very substantial decrease in killing power takes place with lowering of temperature and this must be borne in mind when fixing the contact period (Twort et al., 1985). In case of organic matter, inactivation efficiency of Water Guard decreases with increasing organic matter concentration. The effect of organic matter is to make it difficult to obtain free residual chlorine. In additional, the penetration of chlorine and, therefore, the destruction of bacteria in particles of suspended matter may be insufficient. It is always necessary that disinfection by chlorine or other agents be completed as a final stage in water, which is free from turbidity (Mmbando, 2004). With regard to $\mathrm{pH}$, low $\mathrm{pH}$ brings higher inactivation rates. This is because free chlorine acts more rapidly in acid or neutral water than under alkaline condition and this indicates that hypochlorous acid is a more powerful bactericidal agent than ionized hypochlorite. Fair et al., (1994) determine that, the $\mathrm{pH}$ dependency of free chlorine potency collated quantitatively with the dissociation constant of hypochlorous acid. As the $\mathrm{pH}$ value rises, that dissociation favours the production of hypochlorous ion so that at $\mathrm{pH} 9$ only $4.5 \%$ of the free available chlorine with cysts of
Entamoeba hystolytica was greater than at high $\mathrm{pH}$.

\subsection{Potential effect of Water Guard}

Though widely acceptable, the use of Water Guard as disinfectant has some limitation such as limited shelf life, potential to add chlorinated organic by-products namely chlorate, chlorite, chloroform and bromate collectively known as trihalomethane), corresiveness, bad oduour and higher chemical costs than elemental chlorine (Steenderen, et al., (1988). Further limitation is based on the fact that chlorinated water destroys much of the intestinal flora, the friendly bacteria that help in the food digestion (WHO 1993). Chlorinated water also contains chemical compounds called trihalomethanes which are carcinogenic resulting from the combination of chlorine with organic compounds in water (Scully et al., 1985). These chemicals are also known as organochlorides, do not degrade very well and are stored in the fatty tissues of the body. Organochlorides can cause mutations by altering DNA suppress immune system function and interfere with the natural controls of cell growth (Scully et al., 1985). In other findings, a by-product of chlorination in drinking water has been linked to cancer in rats; although these findings cannot be extrapolated to humans should be taken as an indication of the risk that may be associated with the use of Water Guard (Race, 1997). In another study carried out in Harare, Zimbabwe by Jaravaza (1997), the health survey results has been made to link the prevalence of cancer and the consumption of drinking water containing trihalomethanes, however there were no clear association/correlation between the two variables since during the same period there were no analysis carried out for trihalomethanes, making this more complex. It is however clear that case control studies provided more conclusive information especially where diagnosed people may be contacted to verify exposure a good opportunity to investigate the extent to which chlorination of water contributes towards the prevalence of the above mentioned cancer. 


\subsection{CONCLUSIONS}

Water Guard offers a proven and affordable method for providing safe drinking water at household level. From this study, it can be concluded that, there is an increase of residue chlorine as the dosage increases irrespective of from which source the water was drawn. Also the safety of water is obtained even where the residual chlorine is less that $0.1 \mathrm{mg} / 1$. To be effective in developing countries where the level of education is low, proper guidelines about the dosage should be established and made accessible to majority and from this study a dosage of $4.0 \mathrm{~mL}$ per 20-litre capacity container is appropriate for water found in urban areas. This is due to the fact that water is already disinfected before entering the distribution systems also water with turbidity values of 30-35 NTU chlorine dosage of $8 \mathrm{~mL} / 20$ litres plastic container is recommended and this gives residue chlorine of $0.3-0.5$ $\mathrm{mg} / \mathrm{L}$. Also such guidelines should include the type of water source e.g. tap water, well water etc. and their respective amount of Water Guard which also has to vary depending on the water chemistry, temperature, $\mathrm{pH}$, contact time and turbidity Mmbando, (2004).

\subsection{RECOMMENDATIONS.}

- Expiring date and the concentration of the chemical should be clearly printed on the bottle and it should be noted that, excessive chlorine dosage causes the water to have odour and unpleasant taste to some people hence appropriate dosage is highly recommended.

- On the other hand, it is highly recommended that a separate study be carried out to determine the level and exposure of population that consume water treated with Water Guard and the mentioned side effect such as cancers as there is a definite increase in the cases of those effects.

\section{REFERENCES}

APHA, (1992). Standard Methods for the Examination of Water and Wastewater, American Public Health Association, Wahington.

Butterfield, C.N., (1943). Influence of p H and temperature on the survival of coliforms and pathogens when exposed to free chlorine, U.S. Public. Health Report, Vol.58, pp. 1837.

Chang, S.L., (1944). Destruction of microorganism, Journal of American Water Works Association, Vol.36, No. 11, pp.1192.

Fairs, G.M., Kabler, P.W., and Taras, M.J., (1994). The behaviour of chlorine as water disinfectant, Journal of American Water Works Association, Vol.40, No. 10, pp.430.

Jaravaza, M. (1997) Water quality monitoring in Harare, Lake Chivero, a polluted lake. Edited by Dr. N.A.G. Moyo. University of Zimbabwe Publication.

Marcy, J., and Quick, R.E., (2002). World Spotling: The safe water system. A household-based water quality interview program for the developing world, water conditioning and purification magazine.

Metacalf and Eddy., (1995). Waste Water Engineering, Treatment, Disposal and Reuse. McGraw-Hill Ltd, New York.

Mmbando, E., (2004). Effectiveness of water guard as a disinfectant in water treatment. MSc. Thesis, University of Dar es salaam.

Mwambete, K.D., and Manyanga, V., (2006). Microbial quality of drinking water treatment in Dar es Salaam and use of water guard as disinfectant. Tanzania Medical Journal Vol.21 (1)2006: pp.2224. 
Pecora, J.D., Sousa-Neto, M. D. and Estrela, C., (1999). Solucoes irrigadoras auxiliaries do prepare to canal radicular. In: Endodontia-Principios biologicos e mecanicos. Estre C, Figuiredo JAP. Eds Sao Paulo: Artes Medicas; 1999. pp. 552-569.

Scully, F.E., Kravitz, R., Howell G.D., Speed, M.A., and Arber, R.P., (1985). Contribution of protein to formation of trihalomethanes on chlorination of natural water. Water Chlorination: Environmental Impact and Health Effects. Vol 5, pp 807-820, Ann Arbor Science, Ann Arbor, Mich.
Steenderen, R.A., Theron, S.J., and Engelbrecht, A.C.W., (1988). WRC Report 194/1/89, An investigation into the occurrence of trihalomethanes and their precursors in South African drinking waters.

Race, J., (1997). Chlorination of water. Wiley, New York.

Whitlock, E.A., (1953). The application of chlorine in the treatment of water. $W W E$, PP 12. 